\title{
Counselors' Role to Improve The Resilience Broken Home Students of Junior High School
}

\author{
Denok Setiawati, Kartika Mega Islamarinda, Wiryo Nuryono, Najlatun Naqiyah \\ Universitas Negeri Surabaya \\ Surabaya, Indonesia \\ denoksetiawati@unesa.ac.id
}

\begin{abstract}
The purpose of this research is to know the role of counselor to improve the resilience students with broken home family background of the $8^{\text {th }}$ grade - State Junior high school. The type of this research is a qualitative-descriptive approach. The subject of the research is three students with different background problem of broken home family. Data collection techniques are using interviews and documentation to support the existing data. It resulted the role of the Counselor is to provide individual counselling services that able to help students improve their circumstances.
\end{abstract}

Keyword-counselor role; resilience; broken home

\section{INTRODUCTION}

Broken home is one of the familiar terms in the ears of society. Broken home is a condition of loss of family attention or lack of affection from parents caused by some problem, such as divorce, etc. As revealed by [1], broken home family can be seen from two aspects, namely: (a) the family is divided because the structure is not intact, such as one of the head of the family died or has divorced; (b) parents are not divorced but the family structure no longer intact, such as the father or mother is often not at home, and/or does not show affection anymore.

East Java Province contributed the largest divorce rate in Indonesia, with the percentage of $47 \%$ or almost half of the cases of divorce in Indonesia, (Okezone.com). The latest data in 2015 mentioned nearly one hundred thousand cases of divorces in East Java. The disclosure of this divorce case is largely motivated by many factors. However, it dominated by an economic problem. The impact of broken home family is the family members become psychologically unhealthy. In addition, children will experience a personality crisis, so their behavior is often wrong. They experience emotional and even neurotic disorders.

Broken home families are also often associated with negative outcomes in academic achievement, behavior, psychological adjustment, self-esteem and social relationships. According to [2], adolscents with broken home families are usually associated with antisocial behavior and poor academic records. Broken home shows a bad relationship in the family. In line with that disclosed by [3], many cases of juvenile delinquency such as free sex, ditching, aggressive behavior and so on that influenced by a bad relationship with parents as a child.

Ideally the responsibility of children's development involves three educational environments such as family, community and country. Schools as state institutions are expected to facilitate the development of children even though the children's family is in broken home conditions. All areas of education are synergized to foster children's development, one of which is guidance and counseling. when guided well, it hopes that children with broken home family background, they can face problems that occur and can get out of the difficulty that tighten.

School counselor as someone who has competence in the field of guidance and counseling at schools have an important role to help students with broken home family background to become children have resilience to the problem.

If a person has low resilience, then he will easily fall to the negative impacts, but a person with high resilience will quickly position himself on how to behave towards his problem, he will also try his best to keep up with the normal life, and even able to take a learning of a problem that is being faced and positive thoughts that can be developed will be one of his motivations in living and solving problems that are in his face.

Lengnick-Hall, et al. [4] simply defines resilience as the human ability to deal with, overcome, and become stronger over the difficulties that it undergoes. Meanwhile, according to [5] explained that resilience has four basic functions in human life, namely (a) Overcoming difficulties that have been experienced in childhood; (b) Passing through the difficulties of everyday life; (c) Rising again after experiencing traumatic events or major difficulties; (d) Achieving the best achievement. Resilience can help to optimize all self-potential to achieve all the goals in life. Achieving the goal of life by being open to experiences and opportunities.

Resilience, there are several stages of the process that will be passed by someone who has problems until he is able to become a resilient person. According to [6] the process of resilience consists of 4 processes: (a) Succumbing, a condition that describes the decline in the individual so that he succumbs and surrenders to the misfortune that befall him; (b) Survival, 
which describes the individuals who have been dissolved with the misfortune that he has experienced so that he has difficulty to restore positive psychological and emotional functions; (c) Recovery, which shows a positive increase in the individual who is experiencing problems, he began to rise up to grow positive psychological and emotional functions and he is able to develop positively slowly; and (d) Thriving, which is the stage where the individual undergoes rapid development, he is able to get out of the misfortune or problems that befall him.

Resilience also has supporting aspects that can make a person resilient to his problem. According to Dewanti and Suprapti [7] there are seven abilities that can establish resilience in the individual, namely: (a) Emotion Regulation, which is the management of emotions; (b) Impulse Control, i.e. control of encouragement or desire that comes from within the self; (c) Optimism, namely individual belief that aka tone of ease and beautiful time after the difficulties that befall; (d) Causal Analyst, which is the ability to accurately identify the problems faced; (e) Empathy, Ability where individuals can read the signs of the psychological and emotional conditions of others; (f) Self Efficacy, the belief that it is capable to solve problems by using the ability of self to succeed; (g) Reaching Out, the ability of individuals to be able to achieve positive aspects of life after misfortune overrides.

With regard to student resilience with broken home family background, the role of counselor can help to increase student resilience related to the problem that is facing it. The role of counselors in improving student resilience broken home in school is the expected behavior of someone who has authority in guidance and counseling to assist the individual's ability in dealing with and overcoming difficulties experienced.

Referring to the existing phenomenon as previously mentioned, the researcher wanted to reveal about the students' problem with broken home family background related to the aspects of resilience supporters owned, the stage of resilience process that has been achieved, the impact that occurred due to broken home family and also about how is the role of counselors in helping to deal with student problems with a broken home family background.

\section{METHODS}

The research used is qualitative-descriptive research with case study technique. Qualitative Research Method (2010) explains that qualitative research is the focus of attention with a variety of methods, which include interpretive and naturalistic approach to the subject of the study.

Determination of the subject using purposive sampling technique. The point is that the samples taken by considering the characteristics already in the specified and in advance in advance by the characteristics and nature of the population. According [8] the purposive sampling technique is taken and used because there are some considerations that should be considered related to the research that will be implemented, especially in the case of broken home family.
Data collection techniques used were questionnaires, interviews and documentation studies [9]. Questionnaires are used to select students with family background broken home that match the criteria that have been specified previously. Interviews, used to get results based on the focus of the problem about broken home resilience that has been determined. In addition to the research subjects, interviews were also conducted to some people who can support the results of research such as subject families, homeroom, friends, counselors and vice principals in the field of student affairs. Documentation, used as data supporting research results such as student attendance, chocolate book (book task of guidance and counseling), and photographs during the study took place.

Data analysis technique is divided into three paths namely data reduction, data presentation and conclusion. Data reduction is part of an analysis that sharpens, classifies, directs, discards the unnecessary, and organizes the data in such a way that the conclusions can finally be withdrawn and verified.

Data presentation is a set of arranged information that gives the possibility of drawing conclusions and acting. Conclusions and verification, depending on the size of the collection of field notes, coding, storage, and retrieval methods used, the researcher's skills, and the demands of the sponsor. Verification or verification can be made to seek justification and approval, so that validity can be achieved.

Way to know the validity of a data, one of them is triangulation. According to [10] triangulation can be interpreted as a technique that uses two or more methods of collecting data in research on several aspects of human behavior. In this study, researchers used triangulation of data collection techniques namely the validity test through three techniques of collection the data used are questionnaires, interviews and documentation.

\section{RESULT AND DISCUSSION}

The result of the questionnaire that was adopted and modified from AUM KHK (Family Relationship and Relation Division) which was distributed to 258 students of grade VIII SMPN 3 Candi Sidoarjo to get 3 research subjects in accordance with the criteria that have been determined.

Furthermore, based on structured interviews, data on supporting aspects, stages of the resilience process, broken home family impacts were made to 3 research subjects and the role of counselor in improving student resilience broken home. The result of unstructured interviews was also conducted to support the research data conducted to the family of three subjects, friends, counselor, homeroom teacher and also the vice principal of student affairs.

Documentation Study, as supporting tool and complement of case study data which in this research consist of student attendance and also book of chocolate (book of task of guidance and counseling). 
The result of questionnaires with criteria that have been determined, found 3 subjects that meet the standard criteria. The explanation is as follows: (a) Subject 1 (AAP). Subject 1 is the only female child in her family. Subject's parents are divorced since she is about 3 - 4 years old. Her father was an unemployed man and his mother worked out of the island since the divorce took place. She lived with grandparents and maternal grandparents since her parents divorced until grade 6 of elementary school. Since entering junior high, she began living with his father and often experienced conflict with her father. Some of the causes of divorce revealed by her grandmother, it is the existence of disharmony, frequent quarrels within the house, and differences in social and economic strata made by her grandparent from her father. So, her mothers are often become the subject of insults and scorn from her husband's family.

She often feels a longing for his mother who is also rarely communicate with her. Her mother indeed has a husband (step father) and a daughter (stepsister). But the relationship between her and her step father and also her stepsister did not run harmoniously.

Subject 2 is a cheerful child, easily familiar with others, has many friends, active in the classroom and some school activities. Lives with mother, sister, aunt (who is still in school) and also grandparents. He was the first of three children. He has two younger brothers who are still in the elementary school. His mother has a non-permanent job and her father has gone away from the family since he was a kid. According to N (subject 2's friend), his parents have not divorced yet. But his father just left and did not come back until now. In the questionnaire the subject 2 wrote that his father has left him and his family since 7 years ago. He also assumed that his father has died of not going home and not to support the family.

Subject 3 is the third child of 3 brothers. he has two older sisters currently living with his father, while subject 3 lives with his grandmother and grandfather. Since childhood he has been raised by his grandmother and grandfather. Her mother has died when he was a baby, so the 3rd subject has not had time to know how and who is his biological mother. A few months after the incident, his father decided to remarry. And since then the relationship between him, his father and his grandparents began to improve.

Since the marriage, his father made the decision he should remain and live with his grandparents while his two brothers came with his father and stepmother. Since then, his father began to not take responsibility of him. Hid dad also had several times of physical violence to him, even his stepmother had also slapped him due to a minor error. He was also often in bullying environment at school because he used to not enter the class and threatened to not go up to the upper-class level.

Based on the background of the students' problem the efforts made by the counselor to improve their resilience are through the use of individual counseling services. Individual counseling service is a service organized by a guidance and counselor teacher to a counselee (read: student) in order to alleviate the counselee's personal problem, in face-to-face situations of direct interaction between counselor and counselee, discuss various matters about the problem experienced by the counselee. The approach used in helping to improve students' resilience is a cognitive-rooted approach. Cognitive-rooted approaches include behavioral cognitive approach (CBT) and rational emotive behavior (REBT).

The basic hypothesis of REBT is that our emotions are rooted in our beliefs, evaluations, interpretations, and reactions to their broken home family situations. They learn to improve resilience by altering ineffective ways of thinking with effective and rational cognition, and as a result they change their emotional reactions to the situation. The therapeutic process enables clients to apply the REBT change principles not only in emerging problems but also to other life or future issues they may encounter [11].

CBT's approach is focused on the latest problems, regardless of diagnosis, although the past may be presented in therapy in certain situations. Therapeutic goals include symptom therapy, assisting clients in solving their most pressing problems, and teaching client's prevention strategies when reappearing or recurring problems.

\section{CONCLUSION}

The role of school counselors to the children with broken home family circumstances is considered good, where in the handling of school counselors in digging data about the subject as a whole by exploring the problems of the supporters such as friends, neighbors by making a home visits and also direct search of activities to the counselee. The counselor in giving the handler prefers to use individual counseling where individual counseling is perceived as the most imposing counseling technique to the subject in improving students' resilience with broken home family circumstances. The approach used in helping to improve students' resilience is a cognitive-rooted approach. Cognitive-rooted approaches include behavioral cognitive approach (CBT) and rational emotive behavior (REBT).

\section{REFERENCES}

[1] R. Loeber and M. Stouthamer-Loeber, "Family factors as correlates and predictors of juvenile conduct problems and delinquency," Crime and justice, vol. 7, pp. 29-149, 1986.

[2] T. J. Dishion, G. R. Patterson, M. Stoolmiller, and M. L. Skinner, "Family, school, and behavioral antecedents to early adolescent involvement with antisocial peers," Developmental psychology, vol. 27, p. 172, 1991.

[3] S. Yusuf, Psikologi perkembangan anak dan remaja: PT Remaja Rosdakaryam, 2011.

[4] C. A. Lengnick-Hall, T. E. Beck, and M. L. Lengnick-Hall, "Developing a capacity for organizational resilience through strategic human resource management," Human Resource Management Review, vol. 21, pp. 243255, 2011.

[5] A. S. Masten, "Ordinary magic: Resilience processes in development," American psychologist, vol. 56, p. 227, 2001. 
[6] A. M. Hines, J. Merdinger, and P. Wyatt, "Former foster youth attending college: Resilience and the transition to young adulthood," American Journal of Orthopsychiatry, vol. 75, pp. 381-394, 2005.

[7] A. Dewanti and V. Suprapti, "Resiliensi Remaja Putri terhadap Problematika Pasca Orang Tua Bercerai," Jurnal psikologi pendidikan dan perkembangan, vol. 3, pp. 164-171, 2014.

[8] C. R. Kothari, Research methodology: Methods and techniques: New Age International, 2004.
[9] B. Johnson and L. A. Turner, "Data collection strategies in mixed methods research," Handbook of mixed methods in social and behavioral research, pp. 297-319, 2003.

[10] T. D. Jick, "Mixing qualitative and quantitative methods: Triangulation in action," Administrative science quarterly, vol. 24, pp. 602-611, 1979.

[11] G. Corey, Theory and practice of counseling and psychotherapy: Nelson Education, 2015. 